\title{
FAKTOR PENDUKUNG KEBERHASILAN PENERAPAN SISTEM PENJAMINAN MUTU DI PERGURUAN TINGGI
}

\author{
Yuli Kartika Dewi \\ Universitas Ciputra Surabaya
}

\begin{abstract}
The aim of this study is to acknowledge the supporting factors of a successful quality management system, especially in higher education. The core of the Quality Management System is about the system that was issued by the top management to make sure all the processes done properly. ISO 9001 has set out the criteria or requirements for higher education institution applying quality management system. Formerly this standard was applied by manufacturing industries to assure their products fulfill the customer requirements. Furthermore, it would culminate the customer's satisfaction level. Meanwhile, the quality management system regulated by Indonesian Government has had an evolution, especially in the accreditation processes applied for higher education institution, which give small amount of latitude through its many standards to be accomplished by those of which operating in Indonesia. There are some factors that may support and affect the quality management system. Therefore, through this research, the researcher want to quarry the main factor that support the success of quality management system applied in the university. So, the institution will focus all its energy to work on the key factor that influence the success of the Quality Management System in higher education. This research is applying a qualitative method. The researcher interviews some experts with plenty experiences in pioneering Quality Management System in Bina Nusantara University. As a result, the researcher finds that there many factors that determine the success of quality management system application, some of which are the leader's commitment and competencies, leadership model, excellent process and a solid team.
\end{abstract}

\begin{abstract}
ABSTRAK
Penelitian ini bertujuan untuk mengetahui faktor pendukung keberhasilan sistem penjaminan mutu pendidikan tinggi. Inti dari sistem penjaminan mutu adalah mengenai suatu sistem yang dicetuskan oleh manajemen puncak untuk memastikan seluruh proses berjalan dengan tepat. ISO 9001 memuat suatu set kriteria atau persyaratan yang harus dipenuhi oleh institusi perguruan tinggi yang menerapkan sistem penjaminan mutu. Sebelumnya standar ini digunakan oleh industri manufaktur untuk memastikan produk yang mereka hasilkan memenuhi harapan konsumen, lebih jauh lagi hal ini akan meningkatkan kepuasan konsumen. Sementara itu, sistem manajemen mutu yang diatur oleh pemerintah telah mengalami evolusi, khususnya melalui sistem akreditasi untuk perguruan tinggi yang membatasi ruang gerak institusi dengan berbagai standar yang harus dipenuhi oleh perguruan tinggi yang beroperasi di Indonesia. Banyak faktor dapat mendukung dan mempengaruhi sistem manajemen mutu, untuk itu melalui penelitian ini peneliti ingin menggali faktor utama yang mempengaruhi keberhasilan sistem penjaminan mutu di perguruan tinggi. Penelitian ini menggunakan metode kualitatif. Peneliti telah menwawancarai beberapa orang ahli yang memiliki banyak pengalaman dalam memelopori sistem penjaminan mutu di Universitas Bina Nusantara. Hasil dari penelitian ini, ada banyak faktor yang mempengaruhi kesuksesan penerapan sistem manajemen mutu, namun jika disarikan maka faktor yang paling berpengaruh adalah faktor komitmen dan kompetensi pimpinan, tipe kepemimpinan, ketepatan proses, dan tim yang solid.
\end{abstract}

Kata kunci: Sistem Manajemen Mutu, Pendidikan tinggi, Kepemimpinan 
Pendidikan Tinggi di Indonesia dewasa ini dihadapkan pada kenyataan bahwa ukuran keberhasilan dan mutu pendidikan ditetapkan dan dipantau oleh banyak pihak. Pemerintah melalui sistem Akreditasi Perguruan Tinggi dan Pangkalan Data Pendidikan Tinggi (PDDikti) terus memantau kemajuan dari Perguruan Tinggi dan memberikan status tingkatan mutu yang dapat menjamin kualitas jasa pendidikan bagi masyarakat. Lembaga lain seperti Asosiasi profesi serta himpunan alumni pun memiliki kualifikasi yang berbeda terkait keberhasilan perguruan tinggi. Tidak ketinggalan pengguna lulusan dan orang tua memiliki harapan dan pandangan yang mungkin berbeda-beda.

Keberhasilan suatu perguruan tinggi dilihat dari banyak aspek, diantaranya keberhasilan mencapai predikat akreditasi unggulan, keberhasilan mencetak lulusan yang mudah terserap pasar, keberhasilan mengembangkan sumber daya manusia, baik tenaga pendidik maupun tenaga kependidikan menjadi lebih berprestasi dan meningkat secara kemampuan dan pendapatan, keberhasilan mempublikasikan banyak karya ilmiah bereputasi dan keberhasilan dalam menggerakkan organisasi untuk mendukung terciptanya masyarakat mandiri yang lebih maju dalam pemikiran melalui pengabdian masyarakat, serta prestasi lain yang dapat meningkatkan kepercayaan masyarakat pada kualitas yang ditawarkan oleh perguruan tinggi tersebut.

Perguruan tinggi setiap hari berhadapan dengan mahasiswa sebagai konsumen utama yang menerima dan menikmati seluruh proses pendidikan. Sayangnya pendapat, penilaian dan kepuasan mahasiswa tidak mudah tampak atau diukur. Banyak hal yang membuat pihak penyedia jasa pendidikan meragukan hasil survey kepuasan. Mulai dari tingkat kedewasaan mahasiswa yang dinilai belum cukup siap untuk memberikan penilaian terhadap proses pembelajaran maupun

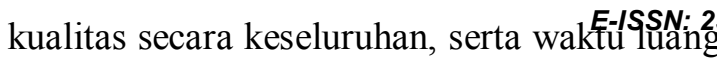
mahasiswa yang terbatas dan mereka pun enggan untuk mengisi kuesioner kepuasan pelanggan dengan serius. Maka kualitas atau keberhasilan penjaminan mutu dalam perguruan tinggi harus melihat aspek lain.

Dalam ISO 9001:2015 disebutkan banyak persyaratan untuk dipenuhi apabila suatu perguruan tinggi hendak memperoleh pangakuan atau sertifikasi ISO 2009:2015. Pemerintah melalui Badan Akreditasi Nasional Perguruan Tinggi (BAN-PT) juga mengatur komponen-komponen prasyarat pengakuan mutu suatu pendidikan tinggi, belum lagi dengan adanya 24 standar minimal dalam Sistem Penjaminan Mutu Internal yang diwajibkan oleh pemerintah untuk dipenuhi oleh seluruh perguruan tinggi di Indonesia. Banyaknya komponen atau faktor yang harus dipenuhi ini membuat energi pelaksana penjaminan mutu terpecah dan sulit untuk fokus menentukan prioritas dalam pekerjaannya.

Dengan latar belakang kenyataan tersebut, penulis ingin mengetahui sebetulnya faktor apakah yang mendukung keberhasilan penerapan penjaminan mutu di perguruan tinggi supaya biro penjaminan mutu dapat mengerahkan energinya dengan fokus pada beberapa faktor untuk mencapai keberhasilan penerapan sistem penjaminan mutu dalam perguruan tingginya.

\section{DEFINISI PENJAMINAN MUTU}

Perdebatan mengenai definisi kualitas telah dimulai lebih dari 1000 tahun yang lalu. Setiap pakar kualitas mendefinisikan kualitas dengan cara yang berbeda-beda. Misalnya ada pakar yang menarik definisi kualitas dari perspektif konsumen, adapula yang menggunakan dasar perspektif spesifikasi produk. Walter Shewhart dikenal sebagai Bapak penemu gerakan kualitas modern dan sebagai penemu aplikasi statistik untuk mengukur kualitas. Shewhart juga dikenal sebagai penemu pendekatan Total Quality 
Management (TQM) yang dikenal luas oleh berbagai praktisi yang bergerak di bidang mutu.

Sebelum berbicara lebih jauh mengenai penjaminan mutu, perlu diketahui definisi mutu.

Menurut Hedwig dan Polla (2006) dikatakan bahwa:

Mutu sering dianggap sebagai ukuran relatif kebaikan suatu jasa yang terdiri atas mutu desain dan mutu kesesuaian. Mutu desain merupakan fungsi spesifikasi jasa, sedangkan mutu kesesuaian adalah suatu ukuran seberapa jauh suatu jasa memenuhi persyaratan atau spesifikasi mutu yang ditetapkan.

Dalam lingkup perguruan tinggi, yang dimaksud dengan penjaminan mutu menurut Hedwig dan Polla (2006) adalah:

Pelayanan jasa yang diberikan oleh perguruan tinggi terhadap stakeholder, yang terdiri dari mahasiswa, alumni, pengguna lulusan/dunia industri, dan orang tua mahasiswa.

Sedangkan menurut Wijatno (2009), definisi Penjaminan Mutu adalah sebagai berikut:

Penjaminan Mutu adalah proses penetapan dan pemenuhan standar mutu pengelolaan secara konsisten dan berkelanjutan, sehingga konsumen, produsen, dan pihak lain yang berkepentingan memperoleh kepuasan.

Dalam bukunya, Sower (2009) mendefinisikan Penjaminan Mutu sebagai berikut:

Quality Assurance (QA) is a broad concept that focuses on the entire quality system, including suppliers and ultimate consumers of the product or service. It includes all activities designed to produce products and services of appropriate quality.

Adapun pemerintah sebagai pihak yang bertanggungjawab terhadap penyelenggaraan pendidikan tinggi di Indonesia, pun telah menetapkan definisi tersendiri atas Penjaminan Mutu.

Menurut Pedoman Penjaminan Mutu Perguruan Tinggi - Dikti 2003, dikatakan bahwa:

"Khusus Pendidikan Tinggi: Penjaminan mutu pendidikan tinggi di perguruan tinggi adalah proses penetapan dan pemenuhan standar mutu pengelolaan pendidikan tinggi secara konsisten dan berkelanjutan, sehingga stakeholders (mahasiswa, orang tua, dunia kerja, pemerintah, dosen, tenaga penunjang serta pihak lain yang berkepentingan) memperoleh kepuasan"

Sedangkan menurut Undang-undang nomor 12 tahun 2012 pasal 52 dikatakan bahwa:

Penjaminan Mutu Pendidikan Tinggi merupakan kegiatan sistemik untuk meningkatkan mutu Pendidikan Tinggi secara berencana dan berkelanjutan.

Dikatakan pula dalam pasal 53 bahwa Sistem Penjaminan Mutu Pendidikan Tinggi terdiri atas Sistem Penjaminan Mutu Internal yang dikembangkan oleh Perguruan Tinggi dan Sistem Penjaminan Mutu Eksternal yang dilakukan melalui akreditasi.

Bila ditarik suatu kesimpulan dari definisi Penjaminan Mutu, maka ditemukan beberapa kata kunci yang serupa, yakni adanya standar mutu pendidikan tinggi yang dapat diukur dan dikendalikan untuk membuat perencanaan mutu pendidikan tinggi yang bermuara pada kepuasan stakeholder/pemangku kepentingan. 
Versi Online: http://journal.ubm.ac.id/

Hasil Penelitian

\section{PERAN DAN TUGAS PENJAMINAN MUTU}

Mutu merupakan janji Perguruan Tinggi pada konsumen pada pendidikan tinggi. Oleh karena itu, Perguruan Tinggi bertanggung jawab terhadap kualitas proses pendidikan dan evaluasinya. Di Indonesia, Sistem Panjaminan Mutu Internal dilaksanakan dan dipantau secara berkelanjutan oleh Lembaga Penjaminan Mutu.

Dalam bukunya, Wijatno (2009) menyatakan:

Pada dasarnya, penjaminan mutu adalah suatu pendekatan yang mengatur pekerjaan yang menjamin bahwa:

1. Misi dan tujuan organisasi jelas bagi semua;

2. Sistem telah dipikirkan secara matang, hampir bebas dari kesalahan, dan dikomunikasikan ke setiap orang;

3. Selalu jelas siapa yang bertanggungjawab atas apa;

4. Mutu didefinisikan secara jelas dan tercatat;

5. Tersedia sistem untuk memerikasi bahwa setiap hal berjalan sesuai rencana; dan

6. Tersedia cara untuk memperbaiki kesalahan.

Sedangkan dalam Hedwig dan Polla (2006) menyatakan bahwa:

Posisi Pusat/Biro/Unit/Kantor

Penjaminan Mutu berada di atas proses.

Dengan demikian, tugas dan fungsi dari

Pusat/Biro/Unit/Kantor Penjamin Mutu adalah:

1. Menjaga seluruh proses yang dijaminkan mutunya;

2. Melihat bagaimana proses itu mempengaruhi satu unit dengan unit lainnya;

3. Mengkoordinasi rapat tinjauan manajemen untuk membahas jalannya penjaminan mutu di unit terkait;
4. Melaporkan setiap kemajuann ${ }^{\text {ISSN:2598-6775 }}$ hambatan yang terjadi dalam implementasi penjaminan mutu;

5. Mencari kemungkinan penympangan yang akan terjadi terhadap suatu proses bernama panel auditor atau MonEvIn;

6. Melakukan evaluasi yang berpengaruh terhadap mutu;

7. Menerima masukan dari stakeholder untuk ditindaklanjuti.

Menilik berbagai pendapat yang telah ada, maka peran dan tugas Penjaminan Mutu adalah menjalankan fungsi manajemen yakni perencanaan, pelaksanaan, pemeriksaan/pengendalian dan perbaikan mutu organisasi. Penjamin mutu memastikan bahwa standar yang telah ditetapkan, dituliskan dalam suatu dokumen baku, disosialisasikan, dipahami dan dilaksanakan oleh segenap anggota yang terlibat dalam proses mutu serta melakukan pengawasan atau pengendalian atas kesesuaian standar dengan yang terjadi di lapangan. Penjamin mutu juga wajib menginisiasi berbagai petimbangan untuk perbaikan mutu Perguruan Tinggi.

\section{FAKTOR YANG MEMPENGARUHI PENJAMINAN MUTU}

Mencermati pentingnya Penjaminan Mutu dan perannya bagi institusi, maka perlu diketahui faktor-faktor yang mempengaruhi keberhasilan dalam penerapan sistem panjaminan mutu di perguruang tinggi.

Menurut Hedwig dan Polla (2006) dikatakan bahwa di dalam struktur organisasi disarankan agar Penjaminan Mutu berada langsung di bawah garis Rektor apabila lingkup penjaminan mutu ada di tingkat Perguruan Tinggi, atau di bawah garis Dekan bila lingkup penjaminan adalah di tingkat fakultas.

Hal lain yang menjadi kunci 
keberhasilan dari penerapan sistem penjaminan mutu di PT menurut Hedwig dan Polla (2006) adalah:

1. Komitmen segenap pimpinan PT;

2. Komitmen manajemen PT;

3. Komitmen setiap individu yang akan menjalankan sistem mutu ini;

4. Konsistensi senantiasa dipelihara dalam setiap melakukan kegiatan maupun pengambilan keputusan/sikap dan

5. Ketersediaan basis data akurat yang digunakan setiap kali pengambilan keputusan.

Dalam ISO 9001 terdapat perubahan pada prinsip manajemen kualitas yakni:

\begin{tabular}{|l|l|}
\hline ISO 9001:2008 & ISO 9001:2015 \\
\hline $\begin{array}{l}\text { Customer - Focused } \\
\text { Organization }\end{array}$ & Customer Focus \\
\hline Leadership & Leadership \\
\hline $\begin{array}{l}\text { Involvement of } \\
\text { People }\end{array}$ & Engagement of people \\
\hline Process Approach & Process Approach \\
\hline $\begin{array}{l}\text { System Approach to } \\
\text { Management }\end{array}$ & Improvement \\
\hline $\begin{array}{l}\text { Continual } \\
\text { Improvement }\end{array}$ & $\begin{array}{l}\text { Evidence-based } \\
\text { Decision Making }\end{array}$ \\
\hline $\begin{array}{l}\text { Factual Approach to } \\
\text { Decision Making }\end{array}$ & $\begin{array}{l}\text { Relationship } \\
\text { Management }\end{array}$ \\
\hline $\begin{array}{l}\text { Mutually Beneficial } \\
\text { Supplier } \\
\text { Relationships }\end{array}$ & \\
\hline
\end{tabular}

Mengamati perubahan yang ditetapkan oleh ISO 9001 terkait prinsip penjaminan mutu, maka faktor penting dari Manajemen Kualitas adalah:

1. Fokus pada Pelanggan

2. Kepemimpinan

3. Keterlibatan SDM

4. Pendekatan proses yang mengutamakan mutu

5. Peningkatan Mutu

6. Pengambilan keputusan yang berbasis data dan fakta

7. Manajemen relasi

Dalam artikel ilmiah yang dipublikasikan melalui laman Direktorat Penjaminan Mutu Kementerian Riset, Teknologi dan Pendidikan Tinggi (http://spmi.ristekdikti.go.id) menuliskan mengenai faktor yang menghambat penerapan mutu internal dari pelaksanaan penjaminan mutu di institusi adalah sebagai berikut:

1. Kurangnya pemahaman civitas akademika dalam Perguruan Tinggi

2. Adanya kelemahan konsistensi, loyalitas serta komitmen dari pimpinan Perguruan Tinggi

3. Adanya ketidaksesuaian pola pikir Yayasan dan pihak manajemen Perguruan Tinggi

4. Lemahnya kepemimpinan dari Pejabat Struktural

5. Kurangnya legalitas atau dasar hukum penerapan Sistem Penjaminan Mutu Internal (SPMI)

6. Kurangnya sosialisasi seluruh dokumen SPMI pada seluruh pemangku kepentingan

7. Kurangnya pelatihan dan pemahaman mengenai SPMI

8. Kebiasaan sumber daya dan manajemen yang bekerja tidak berdasarkan standar yang terpola dengan baik

9. Ketidakjelasan wewenang, tugas pokok dan fungsi dalam organisasi

10. Keterbatasan SDM yang memiliki 
komitmen dan pemahaman SPMI

11. Rendahnya dukungan teknologi Informasi

12. Kurangnya dana untuk pembiayaan SPMI

13. Kesulitan penentuan instrumen keberhasilan pelaksanaan SPMI

Berdasarkan uraian tersebut, jika disimpulkan, maka faktor-faktor yang dapat mendukung keberhasilan pelaksanan Sistem Penjaminan Mutu adalah:

1. Kepemimpinan

Komitmen Pimpinan Perguruan Tinggi, termasuk didalamnya strong leadership dari pimpinan Yayasan maupun pihak Manajemen Perguruan Tinggi

2. Sumber Daya Manusia

Pemahaman Civitas Akademika terhadap pentingnya Sistem Penjaminan Mutu serta kemauan untuk menjalankannya.

3. Sarana pendukung

Pelatihan, sosialisasi SPMI, lembaga SPMI dan teknologi yang mendukung.

\section{UKURAN KEBERHASILAN SISTEM PENJAMINAN MUTU}

Dalam bukunya, Wijatno (2009) menyatakan bahwa Dikti di Perguruan Tinggi dinyatakan bermutu atau berkualitas, apabila:

1. Perguruan tinggi tersebut mampu menetapkan dan mewujudkan visinya melalui pelaksanaan misinya (aspek deduktif); dan

2. Perguruan tinggi tersebut mampu memenuhi kebutuhan pemangku kepentingan (aspek induktif), berupa kebutuhan kemasyarakatan (societal needs), kebutuhan dunia kerja (industrial needs), dan kebutuhan profesional (profesional needs).

Dalam buku yang sama, dikatakan pula bahwa:

ISSN: 1907-0896

Agar penjaminan mutu dikti di perguruan tinggi dapat dilaksanakan, terdapat beberapa prasyarat yang harus dipenuhi agar pelaksanaan penjaminan mutu tersebut dapat mencapai tujuannya, yaitu komitmen, perubahan paradigma, dan sikap mental para pelaku proses dikti, serta pengorganisasian penjaminan mutu di perguruan tinggi.

Keberhasilan penerapan penjaminan mutu eksternal dipantau dan dikendalikan oleh Badan Akreditasi Perguruan Tinggi. Terdapat 8 standar yang harus dipenuhi dan dilampaui yaitu:

1. Kejelasan Visi, Misi, Tujuan dan Sasaran Organisasi

2. Kejelasan Tata Pamong yang menjamin terlaksananya lima pilar tata pamong (kredibel, transparan, akuntabel, bertanggungjawab dan adil) serta karakteristik kepemimpinan yang efektif

3. Mahasiswa dan Lulusan

4. Sumber Daya Manusia

5. Kurikulum, pembelajaran dan suasana akademik

6. Pembiayaan, sarana dan prasarana, serta sistem informasi

7. Penelitian, Pengabdian kepada Masyarakat, dan Kerjasama

Dalam Peraturan Menteri Pendidikan dan Kebudayaan nomor 50 tahun 2014 tentang Sistem Penjaminan Mutu Perguruan Tinggi, disebutkan pula 24 standar minimal yang harus dipenuhi oleh institusi pendidikan tinggi sebagai bagian dari Sistem Penjaminan Mutu Internal. Mulai dari penetapan, pelaksanaan, evaluasi, pengendalian dan perbaikan/peningkatannya.

Pemerintah juga terus memantau kesehatan Perguruan Tinggi melalui analisis data melalui Pangkalan Data Perguruan Tinggi (PD-DIKTI) yang harus dilaporkan setiap semester oleh Kopertis wilayah masing- 
masing.

Berdasarkan uraian di atas, dapat disimpulkan bahwa keberhasilan penerapan penjaminan mutu Perguruan Tinggi tidak lepas dari keberhasilan penerapan Sistem Penjaminan Mutu Internal, melalui:

Penetapan berbagai standar mutu, kebijakan dan komitmen pimpinan untuk terlibat aktif dalam proses penjaminan mutu internal, perencanaan, pelaksanaan dan pengendalian hasil serta perbaikan yang dilakukan melalui Audit Mutu Internal

Serta melalui Sistem Penjaminan Mutu Eksternal yang dilakukan oleh pemerintah melalui Badan Akreditasi Nasional (BAN-PT), serta pelaporan data Perguruan Tinggi melalui Pangkalan Data Perguruan Tinggi.

Keberhasilan pelaksanaan penjaminan mutu Perguruan tinggi juga nampak nyata melalui berbagai prestasi dan pengakuan mutu tingkat nasional maupun internasional.

\section{PERKEMBANGAN PENJAMINAN MUTU PERGURUAN TINGGI DI INDONESIA}

Penjaminan Mutu Perguruan Tinggi di Indonesia semakin menggeliat 10 tahun terakhir. Hal ini sejalan dengan adanya komitmen pemerintah melalui adanya Badan Akreditasi Nasional (BAN-PT) yang mensyaratkan pemenuhan 7 standar (borang) akreditasi sebagai wujud penjaminan kualitas Pendidikan Tinggi di Indonesia, serta diikuti dengan pemisahan direktorat kementerian pendidikan sekolah dasar dan menengah dengan kementerian pendidikan tinggi di tahun 2014.

Akreditasi Program Studi yang telah ada sejak lebih dari 15 tahun lalu berkembang dengan adanya Akreditasi Institusi sejak sekitar tahun 2012 lalu. Peringkat Akreditasi suatu institusi pendidikan mulai diperhatikan oleh pemangku kepentingan Perguruan Tinggi. Akreditasi yang merupakan salah satu bentuk Sistem Penjaminan Mutu Eksternal (SPME) diharapkan mampu menjadi pelengkap Sistem Penjaminan Mutu Internal yang standarnya telah direncanakan, ditetapkan, dilaksanakan dan dimonitor capaiannya oleh institusi pendidikan tinggi secara mandiri melalui Biro/Kantor Penjaminan Mutu. Dengan adanya 7 standar yang memuat kriteria-kriteria utama dalam pendidikan tinggi diharapkan mampu digunakan sebagai patokan standar kelayakan serta menilai keberadaan institusi pendidikan tinggi apakah memenuhi bahkan melampaui standar czxminimal yang ditetapkan oleh pemerintah.

Selain akreditasi yang dilengkapi dengan borang serta lampiran-lampiran dokumen pendukungnya, Dikti juga mengendalikan kualitas Sistem Penjaminan Mutu Eksternal (SPME) melalui Pangkalan Data Perguruan Tinggi atau disingkat PDDIKTI (dahulu disebut PD-PT). Perguruan Tinggi wajib melaporkan seluruh kegiatan operasionalnya sejak awal ijin diterima, penerimaan mahasiswa baru, data pendidik, data KRS maupun nilai mahasiswa hingga mahasiswa tersebut dinyatakan lulus dari Perguruan Tinggi tersebut. Laporan PDDIKTI wajib dilakukan oleh institusi setiap semester untuk menentukan level kesehatan Perguruan Tinggi tersebut.

Sistem Manajemen Mutu yang dipersyaratkan dalam ISO (International Organization for Standardization) 9001 menjaga kualitas berbasis proses. Pemenuhan kriteria persyaratan ISO 9001 ditambah adanya klausul IWA 2 (International Workshop Agreement) mempertajam kriteria mutu yang harus dipenuhi di dunia pendidikan. ISO 9001 dipergunakan oleh berbagai institusi pendidikan sebagai pendukung tercapainya Peringkat Akreditasi Perguruan Tinggi. 


\section{RINTISAN SISTEM PENJAMINAN MUTU UNIVERSITAS BINA NUSANTARA}

Bina Nusantara (disingkat BINUS) sebagai salah satu perguruan tinggi swasta yang telah berdiri lebih dari 35 tahun pun mengalami jatuh bangun dalam proses pengembangan organisasi mereka. Menurut Narasumber yang sampai hari ini masih berstatus dosen Bina Nusantara serta Rektor di Kalbis Institute (managed by Bina Nusantara), pengalaman Bina Nusantara dalam memelopori jaminan mutu sesuai standar ISO 9001 sejak tahun 1996 berhasil cukup baik dan dapat dijadikan teladan oleh Perguruan Tinggi di Indonesia. Pada tahun 1996/1997 BINUS mulai merintis mengenai penjaminan mutu dengan menggunakan sumber/referensi dari Inggris yang memuat 80 standar yang harus dipenuhi oleh Perguruan Tinggi demi menyajikan jasa pendidikan yang terjamin kualitasnya. Waktu itu ISO 9001 masih dipergunakan terbatas untuk menjamin kualitas proses di manufaktur. Belum diterapkan untuk penjaminan mutu jasa maupun bidang pendidikan; namun pimpinan BINUS dengan komitmen tinggi telah mencanangkan komitmen penjaminan mutu dari level atas sampai bawah. Untuk mewujudkan mimpinya, BINUS memulai dengan mengadakan training-training Quality Awareness untuk mengubah pola pikir seluruh personil terkait untuk mengutamakan mutu dalam seluruh proses yang ada di BINUS. Pembentukan tim eksekutif dan tim pelaksana membuktikan keseriusan BINUS untuk menjadi pionir Penjaminan Mutu Pendidikan Tinggi di Indonesia. Tim Eksekutif bertugas melakukan sosialisasi system manajemen mutu serta memotivasi seluruh personil untuk terlibat dalam seluruh proses yang berlangsung di BINUS sedangkan Tim Pelaksana lebih berperan dalam pengembangan system mutu. Struktur organisasi biro penjamin mutu pada masa awal dapat dikatakan sangat sederhana, hanya ada Management Representative (MKE-'SSN: yang $^{2598-6775}$ membawahi bagian Quality Control, yang berperan dalam penyusunan dan pemeliharaan dokumen mutu serta Panel Auditor yang berperan melakukan monitoring dan evaluasi kesesuaian antara prosedur tertulis dengan proses yang berlangsung di lapangan melalui proses audit internal dan eksternal. Sertfikasi ISO yang pertama dilaksanakan pada tahun 1997 dengan melibatkan seluruh jajaran dalam organisasi.

Proses penanaman budaya mutu di BINUS bukan merupakan hal yang mudah. Budaya mutu ini meliputi kesadaran, pemahaman serta komitmen mutu yang baik. Hal ini dikarenakan banyaknya personil dengan pemikiran konvensional yang menentang upaya penjaminan mutu dijalankan, terutama personil yang lama masa kerjanya cenderung telah nyaman dengan kondisi yang ada. Penanaman kesadaran mutu mulai mendarah daging sekitar tahun 2005. Artinya diperlukan waktu sekitar 8 tahun sejak awal dicetuskannya komitmen mutu oleh pimpinan dan sistem penjaminan mutu dijalankan di BINUS.

Proses penanaman budaya mutu ini dilakukan dengan mengadakan sosialisasi berkelanjutan kepada seluruh level jabatan, mengadakan program reward dan punishment yang mendesak dan memaksa seluruh komponen organisasi mengikuti dan terlibat dalam proses penjaminan mutu. Menurut Narasumber, terkadang lebih sulit menanamkan kesadaran mutu pada middle up dibandingkan meminta middle down untuk terlibat dan mengikuti aturan dalam upaya penjaminan mutu.

\section{INDIKATOR KEBERHASILAN PENJAMINAN MUTU PERGURUAN TINGGI}

Menurut narasumber, indicator keberhasilan penjaminan mutu Perguruan Tinggi dapat terlihat dari:

1. Tercapainya visi 
Visi yang dirumuskan dan ditetapkan oleh pimpinan puncak memerlukan komitmen yang cukup kuat sehingga seluruh komponen dalam organisasi, serta seluruh sumber daya yang ada dapat diarahkan dan dipakai semaksimal mungkin untuk mencapai visi tersebut. Visi memuat harapan di masa depan serta diturunkan dalam berbagai strategic plan yang memuat janji-janji pada stakeholder. Penjaminan mutu dikatakan berhasil apabila janji-janji atau target yang telah ditetapkan dapat terealisasikan sesuai dengan milestone capaian.

\section{Peringkat Akreditasi}

7 Standar Akreditasi yang telah ditetapkan oleh pemerintah melalui Badan Akreditasi Nasional (BAN-PT) berisi indikator2 capaian yang memuat standar yang harus dipenuhi oleh institusi pendidikan tinggi. Fungsi Penjaminan Mutu nampak dalam setiap butir mutu yang diuraikan dalam borang Akreditasi. Penjaminan Mutu tidak hanya berarti Biro Penjamin Mutu, namun secara peran dan fungsi melekat dalam setiap jabatan dalam organisasi. Bagaimana setiap personil melakukan tugas keseharian mereka dan mengupayakan hasil terbaik sesuai nilai tertinggi dalam kriteria Akreditasi yang telah ditetapkan. Biro Penjamin Mutu hanya bertugas mengawal seluruh kegiatan/proses yang berlangsung dan melakukan monitoring dan evaluasi melalui proses Audit Mutu Internal yang telah dijadwalkan dan diselenggarakan secara mandiri oleh Perguruan Tinggi. Dengan adanya Penjaminan Mutu, diharapkan seluruh proses yang ada dapat terlaksana sesuai dengan standar yang ditetapkan sehingga peringkat Akreditasi yang unggul dapat tercapai. Capaian tersebut diharapkan mampu mencerminkan kualitas Perguruan Tinggi, khususnya kualitas Program Studi yang ada pada institusi tersebut

\section{Pengakuan Pihak Eksternal}

Pengakuan pihak Eksternal dalam hal ini salah satunya nampak melalui berbagai pemeringkatan Perguruan Tinggi yang dilakukan oleh Dikti, Lembaga Koordinasi Perguruan Tinggi Swasta (Kopertis) serta Lembaga Pemeringkatan lain turut menjadi ukuran keberhasilan penjaminan mutu institusi. Semakin tinggi peringkat yang disematkan pada suatu institusi, kepercayaan masyarakat akan mutu institusi tersebut pun diharapkan akan semakin meningkat. Berbagai indikator yang ditetapkan, memaksa perguruan tinggi bergerak dinamis mengarahkan diri mengerahkan seluruh kemampuan untuk mencapai target yang diharapkan.

\section{Kepuasan Stakeholder}

Stakeholder Perguruan Tinggi memegang peranan penting. Stakeholder memiliki ekspektasi yang cukup besar terhadap Perguruan Tinggi sebagai lembaga yang menghasilkan lulusan siap pakai. Selain kemampuan akademik di bidang masingmasing, penanaman karakter unggul selama proses pembelajaran diharapkan mampu menambah nilai jual lulusan di bursa kerja. Stakeholder yang merasa puas akan menaruh kepercayaan lebih besar dan investasi yang juga lebih besar pada institusi pendidikan tersebut. Oleh karena itu, penjaminan mutu dikatakan berhasil apabila terjadi kepuasan stakeholder.

\section{Peningkatan Jumlah Mahasiswa}

Sebagai bagian yang tak terpisahkan dari kepuasan stakeholder, maka keberhasilan penjaminan mutu yang mudah dilihat adalah peningkatan jumlah mahasiswa. Apabila penjaminan mutu berjalan dengan baik, stakeholder merasa dipuaskan, nilai institusi perguruan tinggi tersebut akan meningkat di mata masyarakat luas. Hal ini 
menimbulkan peningkatan kepercayaan masyarakat akan kualitas pendidikan yang akan mereka terima, dan bermuara pada peningkatan jumlah mahasiswa.

\section{FAKTOR}

PENDUKUNG KEBERHASILAN PENJAMINAN MUTU PERGURUAN TINGGI

1. Komitmen dan kompetensi Pimpinan Pimpinan memegang peranan yang sangat penting dalam keberhasilan Penjaminan Mutu. Di Perguruan Tinggi setiap proses yang berlangsung memerlukan konsistensi dan ketepatan layanan yang tinggi. Hal ini tidak akan terlaksana tanpa adanya komitmen pimpinan untuk mengarahkan segenap sumber daya yang ada pada proses yang bermutu.

Selain komitmen, kompetensi pimpinan juga turut menentukan keberhasilan penjaminan mutu Perguruan Tinggi. Pimpinan yang pernah terlibat dalam proses penyusunan standar mutu, menjadi pelaksana proses mutu dalam institusi akan terasah oleh waktu dan memiliki pengalaman dan kepakaran yang cukup untuk memimpin, mengarahkan dan menjalankan sistem penjaminan mutu yang total dari level atas hingga terbawah.

Dengan adanya komitmen sebagai wujud kemauan yang kuat disertai dengan kompetensi sebagai wujud kemampuan yang besar, maka pimpinan akan mampu menularkan komitmen dan memberikan arahan yang jelas untuk memastikan seluruh proses berjalan sesuai dengan standar dan menggerakkan seluruh komponen dalam institusi bergerak bersama mencapai visi dan target yang telah ditentukan.

2. Fokus pada mutu proses

Kualitas proses yang melekat pada kualitas personil, perlahan harus diubah menjadi standar kualitas proses dalam departemen maupun institusi. Sehingga apabila terjadi pergantian personil, baik karena promosi maupun mutasi ke bagian lain, proses yang
ISSN: 1907-0896

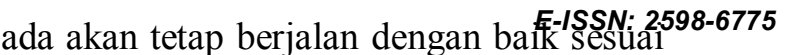
dengan standar yang telah ditetapkan.

Kualitas institusi tidak lagi bergantung pada kualitas bawaan dari personil, sehingga dapat terus ditingkatkan melalui proses evaluasi dan monitoring yang dilakukan dan dilaporkan ke pimpinan puncak oleh Biro Penjaminan Mutu.

ISO 9001 adalah salah satu management tools untuk memastikan proses di lapangan berjalan sesuai dengan standar yang telah ditetapkan, serta memastikan adanya perbaikan berkelanjutan untuk pengembangan kualitas dan institusi. Internal Audit yang dilaksanakan secara teratur dan berkelanjutan serta dengan adanya Rapat Tinjauan Manajemen (RTM) adalah juga sebagai bentuk komitmen pimpinan terhadap perbaikan dan peningkatan mutu.

3. Tim kerja yang solid dan kompeten

Salah satu pernyataan yang tertulis dalam dokumen Binus Quality Management System yang disampaikan setiap induksi karyawan baru, "Jangan menerima input yang tidak sesuai, kecuali ada catatan khusus, jangan menghasilkan ketidaksesuaian, jangan mengirimkan ketidaksesuaian ke proses berikutnya"

Hal ini disampaikan sebagai upaya penanaman kesadaran dan komitmen mutu dalam seluruh proses yang dilakukan di Binus. Menurut nara sumber yang telah kami wawancarai, tidak dipungkiri bahwa hal yang tersulit dalam upaya penanaman kesadaran mutu adalah mengubah mindset sumberdaya manusia yang masih konvensional dan tidak mementingkan mutu. Dengan adanya manusia-manusia yang sadar dan komit terhadap mutu, maka akan timbul tim kerja yang solid dan kompeten dalam menjaga mutu proses yang berlangsung.

\section{SIMPULAN}

Penjaminan dan perbaikan mutu adalah hal yang mutlak perlu dilakukan selama institusi 
mengharapkan peningkatan income.

Penjaminan mutu memegang peranan penting bagi keberlanjutan institusi khususnya di Perguruan Tinggi dengan jumlah proses yang banyak serta dituntut kualitas proses dalam layanan yang diberikan. Keberhasilan penjaminan mutu tak lepas dari faktor komitmen dan kompetensi pimpinan, fokus pada mutu proses, dukungan tim yang solid serta memiliki kesadaran dan komitmen yang cukup kuat untuk menjalankan dan menjaga setiap proses dapat berlangsung sesuai dengan standar yang telah ditetapkan.

\section{SARAN}

1. Bagi institusi Pendidikan Tinggi Institusi Pendidikan Tinggi yang masih berusia belia, secara khusus bagi Universitas Ciputra yang sedang bergerak dinamis mengembangkan sistem penjaminan mutu, disarankan untuk:

a. memfokuskan energi pada faktorfaktor pendukung keberhasilan sistem penjaminan mutu yang telah dijabarkan dalam uraian pembahasan.

b. mengukur, mengevaluasi dan meningkatkan segala capaian atau keberhasilan yang diraih untuk bahan analisis dan penentuan strategi kebijakan bagi masa depan.

c. memberikan referensi bila ingin melakukan pembelajaran lanjutan terkait penjaminan mutu

2. Bagi Pimpinan Perguruan Tinggi

Penelitian ini mempertegas bahwa faktor pendukung yang mempengaruhi keberhasilan penjaminan mutu adalah faktor komitmen dan kompetensi pimpinan. Untuk itu, disarankan agar pimpinan Institusi:

a. menyediakan waktu lebih untuk mengikuti berbagai lokakarya atau segala kegiatan peningkatan mutu yang dilakukan oleh Dikti/Kopertis. Hal ini perlu dilakukan agar pimpinan lebih termotivasi dan memperkuat komitmen atas mutu, sekaligus meng-update informasi terkait aturan-aturan baru yang ditetapkan oleh pemerintah.

b. menyediakan waktu untuk terlibat aktif dalam proses penjaminan mutu, terutama mendukung penyelenggaraan Rapat Tinjauan Manajemen (RTM). RTM diharapkan tidak hanya diketahui, namun dapat menjadi bahan perbaikan berkelanjutan.

c. menyediakan waktu untuk terus belajar baik dari proses internal, maupun dari hasil studi banding. Hal ini perlu dilakukan untuk menambah pengetahuan, mengetahui urgensi Penjaminan Mutu dan meningkatkan kompetensi di bidang penjaminan mutu

d. mengenal kemampuan timnya dan terus memotivasi serta mengarahkan setiap anggota untuk membangun dan menularkan budaya mutu dsalam institusi.

3. Bagi Peneliti berikutnya

Faktor yang telah diuraikan, sangat menarik untuk di teliti lebih lanjut, untuk itu penulis menyarankan pada peneliti berikutnya untuk:

a.mengeksplorasi lebih dalam terkait berbagai faktor keberhasilan penjaminan mutu

b. mengadakan penelitian untuk menguji keterkaitan antara ukuran keberhasilan penjaminan mutu dengan faktor pendukungnya 
DAFTAR PUSTAKA

Pedoman Penjaminan Mutu Perguruan Tinggi - Dikti 2003

Hedwig dan Polla, 2006, Model Sistem Penjaminan Mutu Proses Penerapannya di Perguruan Tinggi

Kartika, 2010, Hambatan Dalam Penerapan Mutu Internal Dari Pelaksanaan Penjaminan Mutu di Akademi Kebidanan Islam Al-Hikmah Kabupaten Jepara, Buku Praktik Baik Sistem Penjaminan Mutu Internal di Perguruan Tinggi, http://spmi.ristekdikti.go.id

Musnaini, Faktor-Faktor yang Mempengaruhi Manajemen Mutu Terpadu Pada Produktivitas Pendidikan Tinggi di Jambi

Sower, 2009, Essentials of Quality with cases and experiential exercises

Undang-undang nomor 12 tahun 2012

Wijatno, 2009, Pengelolaan Perguruan Tinggi Secara Efisien, Efektif dan Ekonomis 